\title{
Services Policy Reform and Economic Growth in Transition Economies, 1990-2004*
}

\author{
Felix Eschenbach \\ Groupe d’Economie Mondiale, Institut d'Etudes Politiques, Paris \\ Bernard Hoekman \\ Groupe d’Economie Mondiale, Institut d’Etudes Politiques, Paris; World Bank; and \\ CEPR
}

\begin{abstract}
Major changes have occurred in the structure of former centrally planned economies, including a sharp rise in the share of services in GDP, employment and international transactions. However, large differences exist across transition economies with respect to services intensity and services policy reforms. We find that reforms in policies towards financial and infrastructure services, including telecommunications, power and transport, are highly correlated with inward FDI. Controlling for regressors commonly used in the growth literature, we find that measures of services policy reform are statistically significant explanatory variables for the post-1990 economic performance of transition economies. These findings suggest services policies should be considered more generally in empirical analyses of economic growth.
\end{abstract}

JEL classification: F14, F43, O14, O40

Keywords: Services, economic growth, transition economies

World Bank Policy Research Working Paper 3663, July 2005

The Policy Research Working Paper Series disseminates the findings of work in progress to encourage the exchange of ideas about development issues. An objective of the series is to get the findings out quickly, even if the presentations are less than fully polished. The papers carry the names of the authors and should be cited accordingly. The findings, interpretations, and conclusions expressed in this paper are entirely those of the authors. They do not necessarily represent the view of the World Bank, its Executive Directors, or the countries they represent. Policy Research Working Papers are available online at http://econ.worldbank.org.

* Mailing address: Groupe d'Economie Mondiale, Sciences-Po, 197 Boulevard St. Germain, Paris 75007. E-mails: FelixEschenbach@yahoo.com; Bhoekman@worldbank.org. We are grateful to Harry Broadman, Beata Javorcik, Robert M. Stern and Alan Winters for comments on earlier drafts, and to Francis Ng and Julia Woertz for assistance with data. 


\section{Services Policy Reform and Economic Growth in Transition Economies, 1990-2004}

One of the stylized facts of economic development is that the share of services in GDP and employment rises as per capita incomes increase (Francois and Reinert, 1996). This reflects increasing specialization and exchange of services through the market ("outsourcing")——with an associated increase in variety and quality that may raise productivity of firms and welfare of final consumers, in turn increasing demand for services. It also reflects the limited scope for (labor) productivity in provision of some services, implying that over time the (real) costs of these services will rise relative to merchandise, as will their share of employment (Baumol, 1967; Fuchs, 1968). Services are increasingly becoming tradable as a result of the greater mobility of people and technological change. This further increases the scope for specialization in production and trade. The competitiveness of firms - both domestic enterprises operating on the local market and exporters on international markets-depends importantly on the availability, cost and quality of producer services such as finance, transport, and telecommunications.

Services industries were generally neglected under central planning. Marxist thinking emphasized the importance of tangible (material) inputs as determinants of economic development, and classified employment in the services sector as unproductive. The lack of producer services was reflected in transport bottlenecks, queuing for and low quality of telecommunications, the absence of efficient financial intermediation, and much lower employment in services than was the case in OECD countries (e.g., less than 1 percent of the labor force was employed in finance and insurance) (Bicanic and Škreb, 1991). Many of the services that are critical to the functioning of a market economy simply did not exist—not just a financial sector that could allocate investment funds efficiently, but also design, advertising, packaging, distribution, logistics, management, after sales services, etc.

In this paper we analyze the impact of service sector policy reforms on the growth performance of 24 transition economies. There are large differences in economic performance across these transition economies. Our primary objective is to explore to what extent servicesrelated policies help explain these differences. We start with a brief discussion of shifts in the structure of these economies and developments in trade and inward FDI in services (Section 1). We then summarize the prevailing policies towards trade and investment in services and the changes that have occurred since the early 1990s (Section 2), focusing in particular on so-called backbone service industries: finance, telecommunications and infrastructure (including utilities). In Section 3 we investigate the impacts of services policies and reforms on growth, controlling 
for standard explanatory variables commonly used in the literature. We find that services policies are an important determinant of growth performance; the coefficient estimates on aur reform indices are all statistically significant. Section 4 concludes.

\section{Shifts in the Structure of Services in Transition Economies}

The share of services in GDP and employment has grown significantly since 1990 in almost all transition economies. Compared to the high income OECD average in 1990-when the share of services in employment and GDP was around 63 percent-countries in Europe and Central Asia (ECA) lagged far behind: services accounted for 30-40 percent of GDP and employment. As of 2003, services shares had increased substantially. The greatest growth is observed in the Baltic States, which have almost converged on the OECD average of 68 percent in terms of GDP shares, although employment shares remain lower (Figure 1). The Central and Eastern European (CEE) countries that acceded to the EU in 2004 have also converged to a large extent. Much less progress has been made by the Central Asian countries, where natural resource-based activities continue to constitute a major share of GDP. ${ }^{1}$

Figure 1: Changes in the Share of Services in GDP and Employment
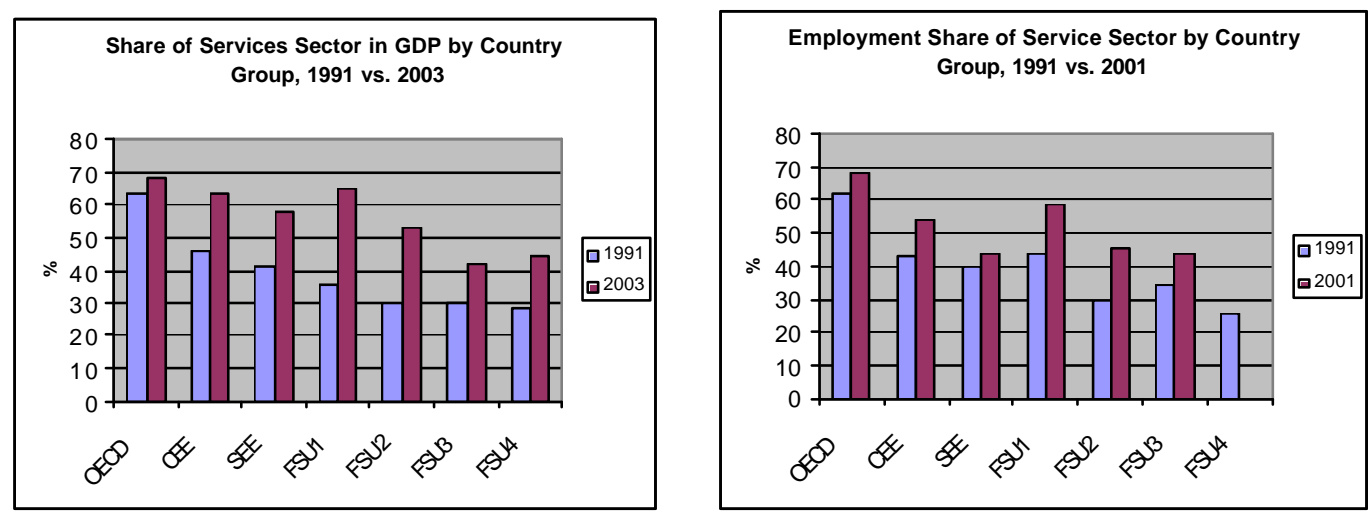

Source: World Bank World Development Indicators.

Note: $\mathrm{CEE}=$ Central and eastern European countries (Poland, Hungary, Czech and Slovak Republics, Slovenia); SEE = Albania, Bosnia and Herzegovina, Bulgaria, Croatia, FYRR Macedonia, Romania, and Serbia and Montenegro; FSU1= Estonia, Latvia and Lithuania; FSU2=Russia, Ukraine, Belarus, Moldova; FSU3 = Armenia, Azerbaijan, Georgia; FSU4 = Kazakhstan, Kyrgyzstan, Tajikistan, Turkmenistan, Uzbekistan.

There is also a distinct pattern in labor productivity performance. The CEE, South-East European (SEE) and Baltic states register an increase in productivity, both overall and within services (broadly defined to include government). ${ }^{2}$ Conversely, for those other countries where

\footnotetext{
${ }^{1}$ See Figure 1 for the definition of country groups used in this paper.

${ }^{2}$ Output data is measured in constant 1995 US dollars, as reported in the World Development Indicators.
} 
data is available, there has been a decline in the measured value of services output per employee. These countries also have not increased their overall labor productivity performance in the last decade. Noteworthy is the performance of the Baltic countries, where labor productivity in services outpaced the productivity increase in other sectors of the economy. Convergence with respect to high-income OECD countries in terms of productivity levels is still far from being achieved, however.

\section{Figure 2: Labor productivity}
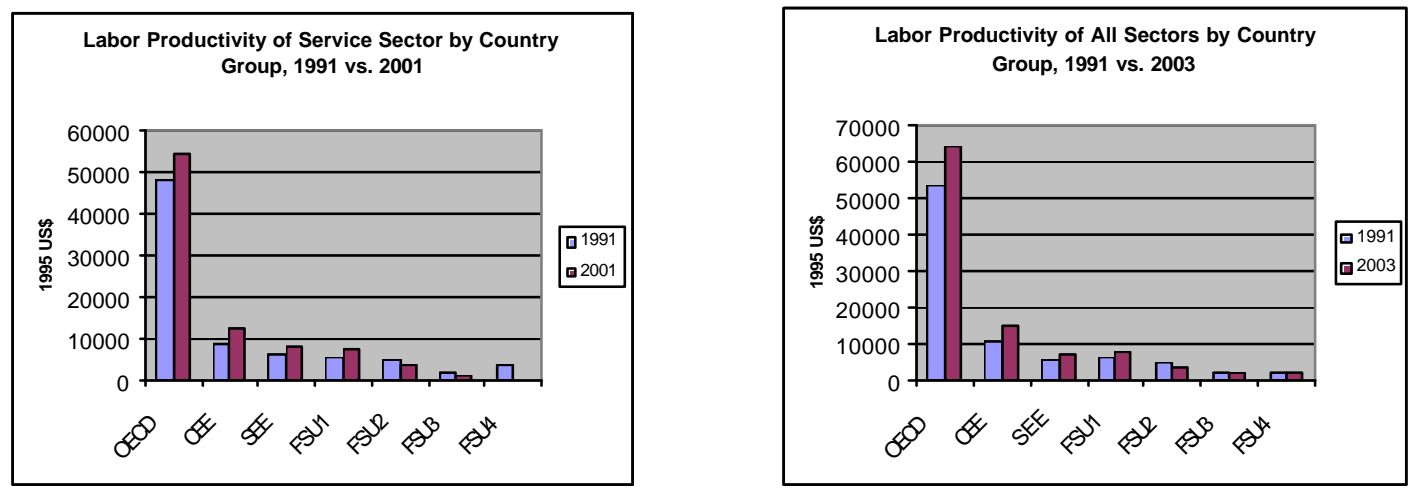

Note: For definition of country groups, see Figure 1.

Input-output tables for the year 2001, the latest available year for many ECA countries, provide information on differences in economic structure and the extent to which ECA countries have converged to comparators in the rest of world as regards both intermediate services use and final demand, as well as on the service intensity of exports. Table 1 reports information on the sectoral intensity of exports: the direct contribution of agriculture, mining, manufactures and services to total exports, expressed as a share of total exports of goods and services. Albania, Croatia and the Baltic States are the most services-intensive in exports. The first column in Table 2 reports the sum of the direct and indirect linkage effects generated by a unit of export revenue - the total activity generated by (going into) one unit of foreign exchange (exports). The average "multiplier" is 3.6, i.e., every US\$ of exports generates $\$ 3.6$ in economic activity. On average a little over one third of this total activity is services-related, ranging from a high of 52 percent (Albania) to a low of 27 percent (Czech Republic). Many transition countries are more services oriented than developing countries such as China or Malaysia. 
Table 1: Sectoral Share of Total Export Revenue, selected transition economies)

\begin{tabular}{lccc}
\hline & Agriculture/Food/ Mining & Manufactures & Services \\
\hline Albania & 19 & 35 & 46 \\
Croatia & 9 & 49 & 42 \\
Czech Rep. & 5 & 80 & 15 \\
Hungary & 7 & 76 & 17 \\
Poland & 10 & 73 & 17 \\
Romania & 4 & 85 & 10 \\
Slovakia & 4 & 86 & 10 \\
Slovenia & 4 & 81 & 15 \\
Estonia & 11 & 66 & 22 \\
Latvia & 13 & 64 & 24 \\
Lithuania & 13 & 63 & 24 \\
Russia & 40 & 52 & 8 \\
\hline
\end{tabular}

Source: GTAP Input-Output data derived from SAMs for 2001.

Table 2: Total Export Related Activity (direct plus indirect linkages), 2001

\begin{tabular}{|c|c|c|c|c|c|}
\hline & \multirow{2}{*}{$\begin{array}{c}\text { Total } \\
\text { "Multiplier" }\end{array}$} & \multicolumn{4}{|c|}{ Shares } \\
\hline & & Agriculture/Food & Mining & Manufactures & Services \\
\hline Albania & 4.8 & 20 & 4 & 24 & 52 \\
\hline Croatia & 2.9 & 18 & 1 & 36 & 45 \\
\hline Czech Rep. & 3.0 & 10 & 2 & 61 & 27 \\
\hline Hungary & 2.8 & 10 & 2 & 51 & 37 \\
\hline Poland & 4.2 & 17 & 3 & 43 & 38 \\
\hline Romania & 6.6 & 27 & 3 & 39 & 30 \\
\hline Slovakia & 2.9 & 12 & 3 & 57 & 28 \\
\hline Slovenia & 2.9 & 10 & 1 & 58 & 31 \\
\hline Estonia & 2.5 & 15 & 2 & 49 & 35 \\
\hline Latvia & 3.0 & 17 & 1 & 36 & 47 \\
\hline Lithuania & 3.5 & 17 & 4 & 36 & 42 \\
\hline Russia & 3.6 & 14 & 17 & 30 & 39 \\
\hline \multicolumn{6}{|l|}{ Memo: } \\
\hline$\overline{\text { Cyprus }}$ & 2.5 & 10 & 7 & 30 & 52 \\
\hline Turkey & 3.7 & 17 & 2 & 40 & 41 \\
\hline China & 3.7 & 18 & 3 & 62 & 17 \\
\hline Malaysia & 2.1 & 8 & 3 & 64 & 25 \\
\hline Germany & 3.3 & 7 & 1 & 49 & 43 \\
\hline
\end{tabular}

Source: GTAP Input-Output data derived from Social Accounting Matrices for 2001.

Although technology is making it easier to trade services, often a commercial presence remains required to sell services, i.e., FDI. Given the lack of a service sector under central planning, FDI can be expected to play a particularly important role, more so than in countries where incumbent competition confronts foreign providers. Overall, services account for some 62 percent of the stock of FDI in the reporting countries (Table 3 ) ${ }^{3}$ Finance, transport, communications and distribution services account for the largest share of this FDI. The service intensity of FDI in services is highest in the Baltic states, presumably reflecting their relatively small size and limited manufacturing base, and lowest in Romania and the Ukraine. Services FDI

\footnotetext{
${ }^{3}$ Aggregate data on FDI inflows are available for a wider set of countries, but these are not broken down across services sectors.
} 
is also very high as a ratio of GDP in the Baltic States. It is lowest in Romania, Russia and the Ukraine.

Table 3: Inward FDI stock by sector, (end 2003 unless indicated otherwise; shares in total (\%))

\begin{tabular}{lccccccccccccc}
\hline & CZ & HU & PL & SK & SI & EE & LV & LT & BG & CR & RO & $\begin{array}{c}\text { RU } \\
\text { flow }\end{array}$ & UK \\
Sector & 2002 & 2002 & 2002 & & 2002 & & & & & & & $00-02$ & 2002 \\
& & & & & & & & & & & & & \\
\hline Agriculture, forestry, fishing & 0.1 & 1.3 & 0.4 & 0.2 & 0.0 & 0.4 & 1.5 & 0.8 & 0.3 & 0.3 & 0.7 & 0.4 & 2.1 \\
Mining and quarrying & 1.4 & 0.3 & 0.3 & 0.8 & 0.0 & 0.4 & 0.6 & 0.8 & 1.1 & 3.1 & & & 2.4 \\
Manufacturing & 35.5 & 45.8 & 35.8 & 37.5 & 43.3 & 18.2 & 15.5 & 31.1 & 33.4 & 30.6 & 54.3 & $45^{* *}$ & 46.4 \\
Electricity, gas, water supply & 6.9 & 4.6 & 2.6 & 11.7 & 1.0 & 2.4 & 3.4 & 4.4 & 1.0 & 1.1 & & & 1.6 \\
Construction & 1.9 & 1.1 & 2.6 & 0.7 & 0.1 & 2.5 & 1.0 & 1.2 & 2.7 & 0.9 & 2.4 & 2.2 & 2.9 \\
Distribution and repair services & 11.9 & 11.1 & 17.1 & 11.2 & 14.5 & 15.9 & 18.0 & 17.9 & 18.0 & 6.9 & 16.4 & $22 * * *$ & 18.5 \\
Hotels and restaurants & 1.2 & 1.1 & 0.6 & 0.5 & 0.4 & 1.7 & 1.3 & 1.6 & 1.7 & 4.0 & 2.4 & & 2.3 \\
Transport, storage \& comm. & 13.6 & 10.1 & 10.4 & 10.0 & 4.4 & 17.7 & 11.9 & 17.1 & 15.7 & 25.0 & 7.8 & 9.5 & 7.2 \\
Financial intermediation & 15.9 & 10.3 & 21.3 & 23.5 & 18.8 & 28.1 & 15.0 & 15.7 & 17.7 & 24.6 & & 1.8 & 8.1 \\
Real estate, rental \& business act. & 9.3 & 11.7 & 7.5 & 3.2 & 15.2 & 11.4 & 24.5 & 7.3 & 3.9 & 3.1 & & 8.2 & 4.7 \\
Education, health, social work & 0.2 &. &. & 0.4. & 0.1 & 0.1 & 0.1 & 0.2. & 0.3 & 0.0. & & & 2.3 \\
Other community\& personal ser. & 2.4 &. &. & 0.3 & 0.5 & 0.8 & 1.1 & 1.5 & 0.8 & 0.5 & & 0.2 & 1.5 \\
Other not classified activities & 0.0 & 1.0 & 1.4 &. & 1.7 & 0.4 & 6.0 & 0.3 & 3.2 &.. & $16 *$ & 11.0 & \\
Real estate purchases by foreigners &. & 1.5 &. &. &. &. &. &. & &.. & & & \\
& & & & & & & & & & & & & \\
Total services share *** & 56.2 & 47.9 & 60.9 & 49.8 & 55.7 & 78.6 & 78.9 & 62.8 & 65.2 & 64.9 & 45 & 54.6 & 47.5 \\
\hline Value of services FDI stock (\$ bn) & 26.7 & 22.9 & 36.8 & 5.6 & 2.8 & 5.1 & 2.6 & 3.1 & 3.3 & 7.4 & 5.7 & 35.5 & 3.6 \\
Services FDI stock as \% of GDP & 31.6 & 27.7 & 17.6 & 17.6 & 7.7 & 60.7 & 26.8 & 37.8 & 16.6 & 26.1 & 9.4 & 8.2 & 7.3 \\
\hline Notes: NMS: New EU Member States; * Includes finance and business services. ** Covers all industry, including &
\end{tabular}

The forgoing snapshot of trends in the share of services in GDP, employment, output per worker, trade and FDI reveal both substantial convergence towards European countries, but also a distinct difference between Central European/Baltic states and Central Asian and CIS economies. Given that trade and FDI in services can be expected to be associated with the acquisition of new technologies, higher service standards and more effective delivery, these differences should help explain the observed higher labor productivity performance in services in the former. The question explored in the rest of this paper is whether these services developments are determinants of the aggregate growth performance of countries. The services outcome variables are of course endogenous, influenced by the policy stances of governments, so that the focus is on the impact of services policy reforms.

\section{Policy Stances and Service Sector Reforms}

Service sector reform involves a mix of deregulation (the dismantlement of barriers to entry and promotion of competition) and improved regulation (putting in place an appropriate legal 
environment, strengthening regulatory agencies, increasing their independence, etc.). The policy challenge is to achieve a balance between effective regulation and increasing the contestability of markets. Much has been done by transition countries to reform and adapt policies and regulatory regimes for service industries. Figure 3 plots three indicators of the extent of policy reform in banking, non-bank financial services and infrastructure. These indices, constructed by the EBRD, range from 0 to 4.3 , and span the period 1990-2004. ${ }^{4}$ The value of the indices is set at zero for 1989, so that the 2004 value provides a measure of the progress that has been made by countries in converging to "best practice" standards-measured by a maximum value of 4.3. Data are available annually for the 1990-2004 period.

Figure 3: Services Reform Index, 2004

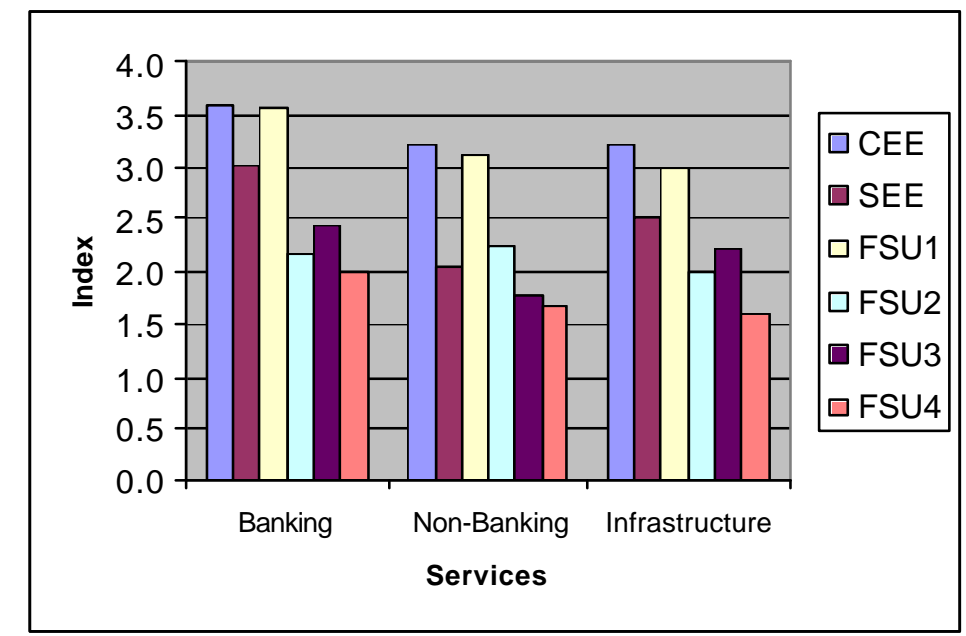

Source: EBRD (2004). See Figure 1 for definition of country groups.

Central and East European (CEE) and Baltic states (FSU1) have made the most progress in all three services policy areas. For the other transition countries there is significant variation across indices. SEE has advanced the most on reforms in banking and infrastructure, followed by the Caucasus (FSU3), while European CIS countries (FSU2) have done the most in the non-bank financial area, followed by SEE. The Central Asian republics have made the least progress in all three areas, with one country—Turkmenistan — not advancing at all in any. What follows briefly discusses current policies for financial and infrastructure services. ${ }^{5}$

\footnotetext{
${ }^{4}$ See Annex 1 for more detailed information on the construction of the EBRD reform indices.

${ }^{5}$ What follows draws on a more detailed discussion in Eschenbach and Hoekman (2005).
} 


\section{Financial Services}

In CEE and Baltic countries the banking sector is presently characterized by small shares of credit allocated through state-owned banks and high foreign participation. Although weaknesses remain in the legal framework (e.g., creditor rights, the bankruptcy code), central bank independence has been strengthened in most of these countries. Cukierman, Miller, and Neyapti (2001) develop a measure of independence that has 16 (weighted) components. They conclude that in CEE and Baltic countries the degree of independence has converged to that of the German Bundesbank in the 1980s. Most other transition countries fall substantially short of this. Their measure reflects only legal, not actual independence. If the latter is taken into account, the divergence across countries increases further. The Central Bank of Belarus, for instance, has a high degree of legal, but a low degree of actual independence.

Banking markets in many FSU countries tend to be relatively closed in either a formal or informal (de facto) sense. However, there is significant variation across countries. Thus, Armenia's financial sector is relatively open and scores higher in terms of regulation. Formal limits on foreign participation (globally or on an individual bank basis) play a role in some countries, but bureaucratic impediments are more prominent in inhibiting foreign participation. Examples include limitations on foreign staff, lengthy licensing procedures, financial repression, public ownership of major banks, and lax regulatory practices. In general the banking sector in these countries suffers from a weak capital base.

\section{Infrastructure Services}

Policy reforms in the area of utility and infrastructure services include better regulation of the provision of these services, removal of cross-subsidization, more efficient pricing, improved revenue collection, and separation/unbundling of activities. Three types of reforms are particularly important in increasing the efficiency of provision of regulated infrastructure services: (i) allowing entry of new domestic and foreign providers; (ii), where feasible, opening the domestic market to imports of such services; and (iii) the establishment of an independent regulator. The latter is likely to be a key determinant of regulatory effectiveness. Reforms may and often do include privatization, but this variable is captured in the overall investment climate variable, not in the infrastructure services policy reform index. Even if incumbent providers remain state-owned, if regulators permit entry of new providers in the market, such competition can be expected to yield efficiency gains in the industry overall. The EBRD indices suggest that 
the CEE and Baltic countries have made the most progress in establishing independent regulators, while many of the CIS countries have made the least.

Figure 4 disaggregates the infrastructure index along five sectoral dimensions-electric power, roads, railways, telecommunications, and water and wastewater-and assesses the cumulative reform progress in each of the ECA countries. On average for the region, progress has been most pronounced in the sectors of telecommunications and electrical power. Often this will reflect a mix of commercialization, deregulation and privatization of national telecom companies. The index shows little or no progress in utility and infrastructure reform in Turkmenistan, Tajikistan Belarus, Uzbekistan, and Kyrgyzstan, with most progress made in Hungary, Poland, the Czech Republic, Estonia and Romania.

Figure 4: Infrastructure Reform, by country and Sector, 2004

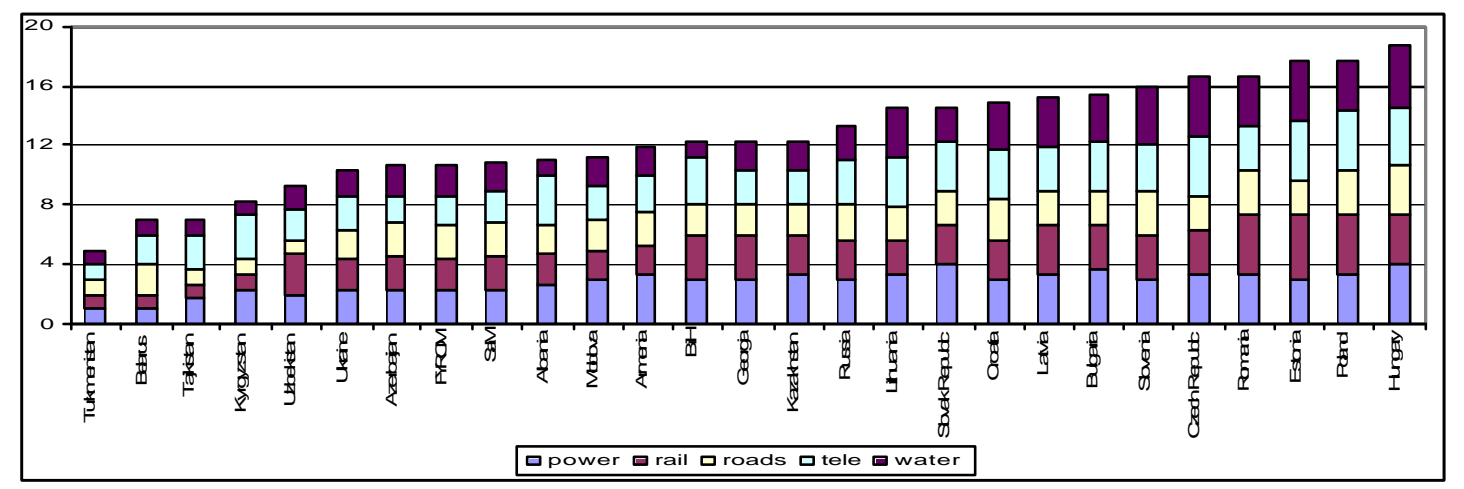

Source: EBRD (2004). The scale ranges from 0 to 20, representing the cumulative progress for each country on the five indic ators, which individually range from 1 to 4.3 - see Annex 1.

In the telecommunications sector, fixed-line services are still quite underdeveloped in most economies. This has given rise to faster growth of, and stronger competition in, the mobile services sectors, especially in CEE and Baltic countries, followed by SEE. In the rest of the FSU, mobile penetration rates fall short of fixed line services. In many of the latter countries, independent telecom regulators have yet to be established. The incumbent fixed-line operator may oppose interconnection agreements; tariffs are frequently low and distorted, and crosssubsidies between different types of calls and customers continue to be prevalent. The least progress has been made in the rail, road and water sectors. Only some CEE countries, (e.g., Poland, Hungary, and Croatia) have introduced private sector participation through toll roads. Reforms in the railway sector are also at an early stage in terms of private sector participation, 
although the separation of infrastructure from operations is either planned or has been put in practice in many countries. ${ }^{6}$

FDI is an important channel for foreign providers to contest infrastructure service markets. FDI in these sectors sometimes takes the form of greenfield investment, but has mostly occurred through privatization. The extent of privatization varies substantially by country and sector, with Central European and Baltic countries the leaders in attracting FDI in infrastructure. The SEE countries have attracted the least.

\section{Services Reforms and Growth Performance}

The foregoing review reveals significant progress but also substantial cross-country heterogeneity in terms of liberalization and reforms in the regulatory framework for key "backbone" services. To what extent does this help explain the significant differences in observed changes in services intensity of economies described in Section 1? Policy reforms should matter for domestic private investment and FDI in services. This is confirmed by simple regressions relating investment climate and the combined service sector reform variables to the stock of FDI as a share of GDP. ${ }^{7}$ This generates coefficient estimates that are statistically significant. The fit of the regressions as reflected in the $\mathrm{R}^{2}$ is high for both measures of policy (Annex Table 2 reports pair-wise correlation coefficients). The higher $\mathrm{R}^{2}$ for model (1) relative to model (2) suggests that services-related policies play an important role in attracting FDI (and more generally, by extension, investment and growth performance). What follows investigates whether FDI (which is often heavily concentrated in services-see Section 2 above) and policy reforms are associated with better overall economic performance (growth). The focus is explicitly on the impacts of the policies towards "producer services" discussed previously.

Standard economic growth theory postulates that growth is a function of capital and labor inputs. It accords no special role to services. Services play a more prominent role in the literature on financial sector development (see Levine, 1997 for a survey), which recognizes that financial intermediaries do not simply passively convert savings into physical investment.

\footnotetext{
${ }^{6}$ In terms of actual reform measures a few examples are worth mentioning. Estonia, for instance, has fully privatized its railway system. Network maintenance is carried out privately in Poland, the Czech Republic, Romania, and Kazakhstan. Passenger services are not profitable in many transition economies and are in general subsidized. In the Czech Republic, Latvia, and Romania the operation of some passenger services has been handed over to private companies. In Russia, Kazakhstan, Poland, and Romania private rail freight services have developed following gradual liberalization in this area. See Eschenbach and Hoekman (2005).

${ }^{7}$ As discussed in Annex 1, the investment climate reform variable measures progress in terms of privatization, price liberalization (including the foreign exchange regime) and corporate governance.
} 
Instead, temporary or permanent growth effects of capital accumulation and productivity improvement are supported by financial intermediaries (banks, capital markets) that actively mobilize savings and channel these towards profit-maximizing investment opportunities. Another strand of the growth literature that (implicitly) emphasizes a services dimension stresses the importance of human capital (education) and R\&D (a "service" activity) in generating (endogenous) growth (e.g., Lucas, 1988, Romer, 1990).

Table 4: Reduced form panel estimates of FDI stocks regressed on policy reform variables

\begin{tabular}{|c|c|c|}
\hline Estimation technique & OLS fixed effects & OLS fixed effects \\
\hline Dependent variable & FDI/GDP & FDI/GDP \\
\hline $\begin{array}{l}\text { Model No. } \\
\text { Independent variables }\end{array}$ & (1) & (2) \\
\hline (a) Service reform index & $\begin{array}{l}18.92 \\
(20.39)^{* * * *}\end{array}$ & \\
\hline (b) Investment climate index & & $\begin{array}{l}17.13 \\
(15.04) * * *\end{array}$ \\
\hline $\mathrm{R}^{2}$ & 0.61 & 0.46 \\
\hline No. of obs. & 203 & 203 \\
\hline
\end{tabular}

The role of producer-services of the type captured by the infrastructure services reform index in the growth process has not attracted much attention in the theoretical or empirical growth literature. Francois (1990) develops a model that points to the importance of such producer services for economic growth, although his model is not dynamic. He argues that the increasing importance of producer services in modern (growing) economies reflects economies of scale and specialization. As firm size increases and labor specializes, more activity needs to be devoted to coordinating and organizing the core businesses of a company. This additional activity is partly outsourced to external service providers. The associated organizational innovations and expansion of "logistics" (network) services yields productivity gains that in turn should affect economy-wide growth performance by enhancing the efficiency of production in all sectors. The associated cost reductions can have the effect of upgrading overall productivity, and are likely to be enhanced by, if not conditional on, increased FDI in services (Konan and Maskus, 2004; Markusen et al., 2005). ${ }^{8}$

\footnotetext{
${ }^{8}$ Most of the quantitative analyses of the impact of services policy reforms has used static applied general equilibrium models. These find that services policies are important for welfare-e.g., Konan and Maskus (2004).
} 
Table 5: Per-capita GDP growth and service sector policies in a panel of 24 transition economies

\begin{tabular}{|c|c|c|c|c|c|c|c|c|c|c|c|c|}
\hline Estimation technique & & & OLS fix & d effects & & & & & $\mathrm{o}$-stage least sc & uares fixed eff & ects & \\
\hline Dependent variable & & & Per-capita & DP growth & & & & & Per-capita & SDP growth & & \\
\hline Model No. & (1) & (2) & (3) & $(4)$ & (5) & (6) & (7) & (8) & (9) & $(10)$ & (11) & (12) \\
\hline Independent variables & & & & & & & & & & & & \\
\hline (a) Investment/GDP & $\begin{array}{l}0.67 \\
(0.74)\end{array}$ & & & & & & $\begin{array}{l}0.17 \\
(1.10)\end{array}$ & & & & & \\
\hline (b) ?Investment/GDP & & $\begin{array}{l}0.56 \\
(5.97)^{* * *}\end{array}$ & $\begin{array}{l}0.39 \\
(4.73)^{* * *}\end{array}$ & $\begin{array}{l}0.44 \\
(2.45)^{* *}\end{array}$ & $\begin{array}{l}0.28 \\
(3.80)^{* * * *}\end{array}$ & $\begin{array}{l}0.32 \\
(4.21)^{* * *}\end{array}$ & & $\begin{array}{l}1.49 \\
(5.62)^{* * *}\end{array}$ & $\begin{array}{l}0.79 \\
(3.57)^{* * *}\end{array}$ & $\begin{array}{l}0.65 \\
(2.05)^{* *}\end{array}$ & $\begin{array}{l}0.70 \\
(3.58)^{* * *}\end{array}$ & $\begin{array}{l}0.72 \\
(3.56)^{* * *}\end{array}$ \\
\hline (c) Inflation & & & $\begin{array}{l}-0.002 \\
(-4.50)^{* * *}\end{array}$ & $\begin{array}{l}-0.006 \\
(-5.36)^{* * *}\end{array}$ & $\begin{array}{l}-0.0011 \\
-2.68 * * *\end{array}$ & $\begin{array}{l}-0.0012 \\
(-3.06)^{* * *}\end{array}$ & & & $\begin{array}{l}-0.002 \\
-(4.09)^{* * *}\end{array}$ & $\begin{array}{l}-.006 \\
(-4.87)^{* * *}\end{array}$ & $\begin{array}{l}-.001 \\
(-2.19)^{* *}\end{array}$ & $\begin{array}{l}-.001 \\
(-2.77)^{* * *}\end{array}$ \\
\hline (d) Crisis & & & $\begin{array}{l}-16.36 \\
(-8.29)^{* * *}\end{array}$ & $\begin{array}{l}-1.77 \\
(-0.59)\end{array}$ & $\begin{array}{l}-12.1 \\
(-6.90) * * *\end{array}$ & $\begin{array}{l}-13.23 \\
(-7.36)^{* * *}\end{array}$ & & & $\begin{array}{l}-15.15 \\
(-6.32)^{* * *}\end{array}$ & $\begin{array}{l}-1.67 \\
(-0.55)\end{array}$ & $\begin{array}{l}-11.27 \\
(-5.20)^{* * *}\end{array}$ & $\begin{array}{l}-12.6 \\
(-5.72) * * *\end{array}$ \\
\hline (e) FDI/GDP & & & & $\begin{array}{l}0.22 \\
(5.61)^{* * *}\end{array}$ & & & & & & $\begin{array}{l}0.21 \\
(5.07)^{* * *}\end{array}$ & & \\
\hline (f) Finance & & & & & $\begin{array}{l}8.29 \\
(10.26)^{* * *}\end{array}$ & & & & & & $\begin{array}{l}8.47 \\
(8.38)^{* * *}\end{array}$ & \\
\hline (g) Infrastructure & & & & & & $\begin{array}{l}6.8 \\
(8.81)^{* * *}\end{array}$ & & & & & & $\begin{array}{l}6.24 \\
(7.11)^{* * *}\end{array}$ \\
\hline Instruments & & & & & & & $\begin{array}{l}\text { lags }(1,2) \text { of } \\
\text { variable (a), } \\
\text { service, } \\
\text { invclim }\end{array}$ & $\begin{array}{l}\text { lags }(1,2) \text { of } \\
\text { variable (a), } \\
\text { service, } \\
\text { invclim }\end{array}$ & $\begin{array}{l}\text { lags }(1,2) \text { of } \\
\text { variable (a), } \\
\text { service, } \\
\text { invclim plus } \\
\text { exogenous } \\
\text { variables = } \\
\text { (c), (d) }\end{array}$ & $\begin{array}{l}\text { lags }(1,2) \text { of } \\
\text { variable (a), } \\
\text { service, } \\
\text { invclim plus } \\
\text { exogenous } \\
\text { variables = } \\
\text { (c), (d), (e) }\end{array}$ & $\begin{array}{l}\text { lags }(1,2) \text { of } \\
\text { variable (a), } \\
\text { service, } \\
\text { invclim plus } \\
\text { exogenous } \\
\text { variables = } \\
\text { (c), (d), (f) }\end{array}$ & $\begin{array}{l}\text { lags }(1,2) \text { of } \\
\text { variable (a), } \\
\text { service, } \\
\text { invclim plus } \\
\text { exogenous } \\
\text { variables = } \\
\text { (c), (d), (g) }\end{array}$ \\
\hline R-squared & 0.01 & 0.09 & 0.29 & 0.26 & 0.37 & 0.37 & 0.01 & 0.04 & 0.24 & 0.25 & 0.32 & 0.33 \\
\hline No. of obs. & 348 & 332 & 329 & 198 & 329 & 329 & 309 & 310 & 309 & 194 & 309 & 309 \\
\hline
\end{tabular}

Note: $\mathrm{t}$-values in brackets, asterisks denote significance at $10^{*}, 5^{* *}$, and $1 * * *$ percent levels. Model $4=17$ countries only. Variables 'service' and 'invclim' are the average services reform index and the investment climate 
In what follows we explore the impact of financial and infrastructure services policy reforms on growth using time-series data for a panel of 24 transition economies covering the 1990-2004 period. Annex Tables 2, 3, and 4 describe the data and the sample, and provide descriptive statistics and pair-wise correlation coefficients. We exclude three countries for which the coverage of macroeconomic data over time is poor (Turkmenistan, Serbia/Montenegro, Bosnia/Herzegovina). We start with simple OLS country fixed effects regressions ${ }^{9}$ (Table 5). The dependant variable is the growth rate of per-capita GDP. In most of the literature, the main factor driving growth is assumed to be investment (e.g., Levine and Renelt, 1992). Transition economies experienced large swings in investment in the first half of the 1990s, with the collapse of central planning and the initial lack of market institutions leading to sharp reductions in investment (Roland, 2000; Falcetti et al, 2002). Subsequently, a gradual buildup of a domestically and externally financed private capital stock occurred. This well-known U-shaped pattern of output and investment collapse and recovery suggests that the change in the investment ratio be used as an alternative to the investment-GDP ratio as a measure of investment. $^{10}$

The reduced form models (1) and (2) test the alternative hypotheses of a linear vs. nonlinear relationship between investment and growth. Investment/GDP is statistically insignificant (model 1), while the change in the ratio is significant. Thus, the initial collapse and the subsequent recovery in GDP growth was associated with changes in the rate of change in investment at a fast pace: first falling and subsequently rapidly growing investment ratios. We therefore use the change in investment in the regressions. In model (3) we add variables to account for crises and inflation. Inflation, a measure of macroeconomic stability, is expected to have a negative impact on growth. Crisis is a dummy variable that equals one in years when countries experienced armed conflict or a major financial crisis. It captures conflicts affecting Georgia, Armenia, Azerbaijan, and Tajikistan and the financial crises in Russia and Albania. These events will be captured in part by other variables, but not completely, and we want to

\footnotetext{
${ }^{9}$ The fixed effects model allows to some extent for heterogeneity across countries.

${ }^{10}$ In the empirical analysis we do not use several variables that are often used in growth regressions. These include measures of human capital, trade openness and initial per-capita income. The reason is that our country sample is quite specific in the sense that all experienced a sharp fall in output in the first half of the 1990s, notwithstanding relatively high levels of human capital. Also, trade volumes during the early transition do not reflect integration with world markets but rather traditional COMECON barter trade relations. As a result of these factors, conditional convergence is not observed in the data, and including these variables yields rather counterproductive results.
} 
control for them explicitly in any event. Both variables have the predicted sign and are statistically significant at the 1 percent level.

In model (4) we include the stock of FDI as a share of GDP to the explanatory variables. Given limited time series data on FDI, this shrinks the sample to 17 countries. Due to the smaller sample size in model (4) the crisis variable is no longer significant. The result suggests FDI is an important factor driving growth. Ceteris paribus, the coefficient estimate indicates that a onepercentage point increase in the FDI/GDP ratio is associated with a 0.22 percentage point increase in the growth rate.

In models (5) and (6) we replace FDI with the annual EBRD reform indices, the premise being that service sector reform policy affects growth indirectly by supporting FDI inflows as well as domestic investment. The indices, summarized in Section 2 above, are constructed to reflect finance and infrastructure policy frameworks in a relatively broad sense (see Annex 1 and Annex Table 2 for details). Both indicators are significant at the one percent level. The coefficients suggest, ceteris paribus, that a one point increase in the reform index (scaled from no reform=1 to 4.3) is associated with an increase in the per-capita growth rate of 6.8 (Infrastructure) and 8.3 (Finance) percentage points. Given the huge differentials in growth rates during the observed period this is not as large as it appears, but still amounts to a sizeable impact. The analysis of the model fit suggests that the reform indices add substantial explanatory power (the $\mathrm{R}^{2}$ increases from 0.29 in model (3) to 0.37 in models (5) and (6) (model (4) is ot directly comparable due to the smaller number of observations).

The banking sector reform measure has a slightly larger effect in explaining observed growth than does the infrastructure policy reform variable. In those transition economies where financial intermediation existed during the 1990s, the output collapse was much less pronounced and the subsequent recovery occurred at a faster pace. ${ }^{11}$ Strengthening the financial sector and bolstering confidence in the private commercial banking sector by improving the policy framework therefore is of great importance. ${ }^{12}$ Indeed in many of the countries in question, potential depositors still shy away from banks and credit remains influenced by or subject to direct or indirect government control. As discussed above, the policy reform agenda in

\footnotetext{
${ }^{11}$ Campos and Coricelli (2002, p. 29ff) and Roland (2000) discuss the importance of missing and underdeveloped credit markets in the early transition period.

${ }^{12}$ This spans adoption of and compliance with good practice standards defined by organizations such as the IMF, BIS, and IOSCO, including credible and effective implementation-cum-enforcement by regulatory authorities.
} 
infrastructure spans many dimensions, including pro-competitive regulation of public providers-tariffs that reflect costs and provide incentives for providers to pursue efficiency improvements, ensuring access to networks and interconnection on reasonable terms, and the development of effective, independent regulatory bodies.

In models (7) to (14) we repeat the exercise using two-stage least squares regression so as to take into account the potential simultaneity bias in the elationship between growth and investment. As instruments we use lags of the investment/GDP ratio and two composite EBRD reform indicators for the domestic investment climate and the service sector policy framework. Both lagged investment and policy indicators are sufficiently exogenous to growth but relate to current investment decisions and are therefore useful as instruments. The results are similar, with the coefficient estimate of the investment variable increasing slightly.

\section{Conclusions}

Controlling for a number of standard explanatory variables used in the growth literature (investment, crises, inflation), we find a statistically significant positive association between percapita GDP growth and indirect (FDI) and direct measures of service sector policy reforms (the different policy choice indices). Although the sample of countries was limited to transition economies-annual policy reform indicators of the type compiled by the EBRD do not exist for developing countries - the findings indicate that services policies should be considered more generally in empirical analyses of economic growth. Services such as finance, telecommunications and transport are major inputs into the production of goods and servicesincluding agriculture as well as manufacturing. The costs of these inputs can account for a major share of the total cost of production, and are thus important factors affecting the competitiveness of firms. Services are also important determinants of the productivity of workers in all sectorseducation, training, and health services are key "inputs" into the formation and maintenance of human capital. Thus, service sector reforms potentially can do much to enhance economic growth and efficiency.

Both the policy and econometric evidence reviewed in this paper suggests a comprehensive "behind-the-border" policy reform agenda focusing on services can help attract much-needed investment, both domestic and foreign. Openness to foreign competition—through policies that permit foreign participation on domestic markets - is a key element of good service 
sector policy. There is no good measure available of the "multiplier" effect of services reform and openness. But the limited stock of inward FDI in Central Asian economies is in striking contrast to the CEE and Baltic countries. So is the overall economic performance of these different countries, measured both in terms of average performance and its volatility. Liberalization-greater participation by foreign service firms on domestic markets- is of course not sufficient. Given the characteristics of services and services markets-often affected by asymmetric information or high fixed costs and associated barriers to entry-there is also need for effective regulatory supervision of both domestic and foreign operators. This is a significant challenge. Given that the CEE, Baltic and increasingly the SEE countries now offer relatively attractive policy environments for FDI and have done much to converge on OECD regulatory standards in services, the policy reform threshold for the Central Asian and other transition countries has become much more competitive. The ongoing Doha Round negotiations-which span services-offer an immediate and important opportunity to pursue further service sector reforms and can help ensure that the domestic policy efforts are made to put into place the needed complementary regulatory framework. 


\section{References}

Baumol, William (1967), "Macroeconomics of Unbalanced Growth," American Economic Review 57: 415-26.

Bicanic, Ivo and Marko Škreb (1991), "The Service Sector in East European Economies: What Role Can it Play in Future Development," Communist Economies and Economic Transformation 3(1): 221-33.

Campos, N. and Coricelli, F. (2002), "Growth in transition: What we know, what we don't, and what we should," Journal of Economic Literature, XL, pp. 793-836.

Cukierman, Alex, Geoffrey P. Miller, and Bilin Neyapti (2001), "Central Bank Reform, Liberalization and Inflation in Transition Economies-An International Perspective," CEPR Discussion Paper 2808.

EBRD (2004), Transition Report, 2004. London: EBRD.

Eschenbach, Felix and Bernard Hoekman (2005), "Services Trade and FDI in Eastern Europe and Central Asia," World Bank, mimeo.

Falcetti, E., Raiser, M. and Sanfey, P. (2002), "Defying the odds: Initial conditions, reforms, and growth in the first decade of transition," Journal of Comparative Economics, 30, 229-50.

Francois, Joseph F. (1990), "Producer Services, Scale, and the Division of Labor," Oxford Economic Papers, 42(4), 715-729.

Francois, Joseph F. and Kenneth Reinert (1996), "The role of Services in the Structure of Production and Trade: Stylized facts from a Cross-Country Analysis," Asia-Pacific Economic Review, 2:35-43.

Fuchs, Victor (1968), The Service Economy. New York: Columbia University Press.

Konan, Denise and Keith Maskus (2004), "Quantifying the Impact of Services Liberalization in a Developing Country," Policy Working Paper 3193, World Bank.

Levine, Ross, and David Renelt (1992), "A sensitivity analysis of cross-country growth regressions", The American Economic Review, 82 (4), 942-963

Levine, Ross (1997), "Financial Development and Economic Growth: Views and Agenda," Journal of Economic Literature, 35(2), 688-726.

Lucas, Robert E. Jr. (1988), “On the Mechanics of Economic Development," Journal of Monetary Economics, 22, 3-42.

Markusen, James, Thomas Rutherford and David Tarr (2005), "Trade and Direct Investment in Producer Services and the Domestic Market for Expertise," Canadian Journal of Economics, forthcoming.

Roland, Gerard. (2000), Transition and Economics: Politics, Markets and Firms, Cambridge, MA: MIT Press.

Romer, Paul M. (1990), "Endogenous Technological Change," Journal of Political Economy, 98(5), 71-102. 


\section{Annex 1: The EBRD Services Reform Indices}

The index ranges from 1(little progress) to 4.3 (most advanced implementation of reform agenda) and has been compiled on an annual basis for the 1990-2004 period.

\section{Finance $=$ average of the following two banking and non-banking reform indicators :}

- Banking and interest rate liberalization: A 4.3 means full convergence of banking laws and regulations with BIS standards, provision of full set of competitive banking services.

- Securities markets and non-bank financial institutions: 4.3 means full convergence of securities laws and regulations with IOSCO standards, fully developed non-bank intermediation.

\section{Infrastructure = average of the following five infrastructure reform indicators:}

- Electric power: 4.3 means Tariffs cost-reflective and provide adequate incentive for efficiency improvements. Large-scale private sector involvement in the unbundled and well-regulated sector. Fully liberalized sector with well-functioning arrangements for network access and full competition in generation.

- Railways: 4.3 means separation of infrastructure from operations and freight from passenger operations.

Full divestment and transfer of asset ownership implemented or planned, including infrastructure and rolling stock. Rail regulator established and access pricing implemented.

- Roads: 4.3 means fully decentralized road administration. Commercialized road maintenance operations competitively awarded to private companies. Road user charges reflect the full costs of road use and associated factors, such as congestion, accidents and pollution. Widespread private sector participation in all aspects of road provision. Full public consultation on new road projects.

- Telecommunications: 4.3 means effective regulation through and independent entity. Coherent regulatory and institutional framework to deal with tariffs, interconnection rules, licensing, concession fees and spectrum allocation. Consumer ombudsman function.

- Water and waste water: 4.3 means water utilities fully decentralized and commercialized. Fully autonomous regulator exists with complete authority to review and enforce tariff levels and quality standards. Widespread private sector participation via service/management/lease contracts. Highpowered incentives, full concessions and/or divestiture of water and waste-water services in major urban areas.

\section{Service = average of Infrastructure and Finance (used in Table 5 as an instrument)}

\section{Invclim = Investment climate measure, the average six EBRD reform indicators:}

- Large-scale privatization: 4.3 means standards and performance typical of advanced industrial economies: more than 75 per cent of enterprise assets in private ownership and significant progress on corporate governance of these enterprises

- Small-scale privatization: 4.3 means standards and performance typical of advanced industrial economies: no state ownership of small enterprises; effective tradability of land.

- Governance and enterprise restructuring: 4.3 means standards and performance typical of advanced industrial economies: effective corporate control exercised through domestic financial institutions and markets, fostering market-driven restructuring.

- Price liberalization: 4.3 means standards and performance typical of advanced industrial economies: complete price liberalization with no price control outside housing, transport and natural monopolies.

- Trade and foreign exchange system: 4.3 means standards and performance typical of advanced industrial economies: removal of most tariff barriers; membership in WTO.

- Competition policy: 4.3 means standards and performance typical of advanced industrial economies: effective enforcement of competition; unrestricted entry to most markets.

Source: EBRD Transition Report, 2004. 


\section{Annex Table 1: Inward FDI Stock, US\$ Million}

\begin{tabular}{|c|c|c|c|c|c|c|c|c|c|c|c|c|c|c|}
\hline & 1990 & 1991 & 1992 & 1993 & 1994 & 1995 & 1996 & 1997 & 1998 & 1999 & 2000 & 2001 & 2002 & 2003 \\
\hline Czech Republic & 72 & 595 & $2,88 \mathrm{c}$ & 3,423 & 4,547 & 7,350 & 8,572 & 9,234 & 14,375 & 17,552 & 21,644 & 27,092 & 38,669 & 47,527 \\
\hline Hungary & 569 & 2,107 & 3,424 & 5,585 & 7,095 & 11,304 & 13,282 & 17,981 & 20,746 & 23,381 & 23,015 & 27,698 & 38,028 & 47,809 \\
\hline Poland & 109 & 425 & $1,37 C$ & 2,307 & 3,789 & 7,843 & 11,463 & 14,587 & 22,479 & 26,075 & 34,227 & 41,247 & 47,900 & $60,500^{1)}$ \\
\hline Slovakia & . & . & . & . & 897 & 1,297 & 2,046 & 2,083 & 2,890 & 3,188 & 4,746 & 5,582 & 8,530 & $11,250^{1)}$ \\
\hline Slovenia & . & . & & 954 & 1,326 & 1,763 & 1,998 & 2,207 & 2,777 & 2,682 & 2,893 & 2,605 & 4,081 & $5,000^{1)}$ \\
\hline Tota I CEE-5 & 750 & 3,127 & $7,68:$ & 12,270 & 17,654 & 29,557 & 37,361 & 46,092 & 63,267 & 72,878 & 86,525 & 104,224 & 137,208 & 172,086 \\
\hline Estonia & . & . & 96 & 239 & 495 & 737 & 838 & 1,148 & 1,822 & 2,467 & 2,645 & 3,160 & 4,226 & 6,511 \\
\hline Latvia & . & . & $4 \vdots$ & 75 & 309 & 615 & 936 & 1,272 & 1,558 & 1,795 & 2,084 & 2,332 & 2,751 & 3,320 \\
\hline Lithua nia & . & . & $2 C$ & 153 & 310 & 352 & 700 & 1,041 & 1,625 & 2,063 & 2,334 & 2,665 & 3,981 & 4,960 \\
\hline Baltic countries & . & . & 15: & 466 & 1,114 & 1,704 & 2,475 & 3,460 & 5,004 & 6,326 & 7,063 & 8,157 & 10,959 & 14,791 \\
\hline Albania & . & . & $2 C$ & 88 & 141 & 211 & 301 & 349 & 394 & 435 & 578 & 786 & 929 & 1,107 \\
\hline Bosnia and Herzegovina & . & . & & . & . & . & . & . & 67 & 244 & 390 & 509 & 774 & 1,155 \\
\hline Bulgaria & 4 & 60 & $10]$ & 141 & 247 & 337 & 446 & 951 & 1,597 & 2,403 & 2,257 & 2,758 & 3,662 & $5,000^{1)}$ \\
\hline Croatia & . & . & . & 120 & 237 & 351 & 862 & 1,395 & 1,903 & 2,578 & 3,560 & 4,706 & 6,711 & 11,351 \\
\hline Macedonia & . & . & . & . & 24 & 33 & 45 & 75 & 203 & 235 & 410 & 851 & 929 & 1,024 \\
\hline Romania & . & 45 & 122 & 216 & 402 & 821 & 1,097 & 2,352 & 4,418 & 5,469 & 6,480 & 7,638 & 9,022 & 12,764 \\
\hline Serbia and M ontenegro & . & . & & . & . & . & . & 740 & 853 & 965 & 1,015 & 1,180 & 1,655 & 2,915 \\
\hline South Eastem Europe & 4 & 105 & 24: & 565 & 1,052 & 1,755 & 2,752 & 5,862 & 9,433 & 12,329 & 14,690 & 18,428 & 23,682 & 35,316 \\
\hline Belarus & . & . & & 18 & $2 \varepsilon$ & 43 & 154 & 506 & 709 & 1,153 & 1,306 & 1,397 & 1,646 & 1,897 \\
\hline Moldova & . & . & & 14 & $2 \varsigma$ & 94 & 117 & 196 & 258 & 323 & 459 & 600 & 727 & 789 \\
\hline Russia & . & . & . & 1,211 & 1,900 & 3,966 & 6,545 & 11,410 & 14,172 & 17,481 & 25,226 & 36,776 & 51,374 & $65,000^{1)}$ \\
\hline Ukraine & . & . & & 370 & 529 & 796 & 1,317 & 1,940 & 2,683 & 3,179 & 3,875 & 4,801 & 5,529 & $7,500^{1)}$ \\
\hline European CIS & . & . & 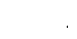 & 1,613 & 2,486 & 4,899 & 8,133 & 14,052 & 17,822 & 22,136 & 30,865 & 43,574 & 59,276 & 75,186 \\
\hline Asian CIS & . & . & $17 \equiv$ & 1,500 & 2,397 & 4,018 & 6,608 & 9,715 & 12,712 & 15,174 & 16,123 & 20,856 & 25,139 & $32,000^{1)}$ \\
\hline All CIS & & & & 3,113 & 4,883 & 8,917 & 14,741 & 23,767 & 30,534 & 37,310 & 46,988 & 64,430 & 84,415 & 107,186 \\
\hline Total & & & & & $24,70=$ & 41,933 & 57,328 & 79,181 & 108,238 & 128,844 & 155,266 & 195,239 & 256,264 & 329,379 \\
\hline
\end{tabular}

Source: wiiw-wifo Database on FDI, July 2004 edition. 
Annex Table 2: Documentation of data used in panel analysis

\begin{tabular}{|c|c|c|c|c|c|}
\hline Variable & Growth & Investment/GDP & ?Investment/GDP & Inflation & Crisis \\
\hline Definition & $\begin{array}{l}\text { Per-capita } \\
\text { GDP growth }\end{array}$ & $\begin{array}{l}\text { Gross fixed capital } \\
\text { formation in } \% \text { of } \\
\text { GDP }\end{array}$ & $\begin{array}{l}\text { Change in } \\
\text { Investment/GDP } \\
\text { ratio }\end{array}$ & $\begin{array}{l}\text { consumer } \\
\text { price inflation }\end{array}$ & $\begin{array}{l}\text { Dummy for } \\
\text { financial } \\
\text { crisis/armed } \\
\text { conflict }\end{array}$ \\
\hline Source & $\begin{array}{l}\text { World Bank } \\
\text { WDI }\end{array}$ & IMF WEO & IMF WEO & IMF WEO & n.a. \\
\hline Variable & $F D I / G D P$ & Finance & Infrastructure & Invclim & Service \\
\hline Definition & $\begin{array}{l}\text { Stock of FDI } \\
\text { as \% of GDP }\end{array}$ & $\begin{array}{l}\text { Average of EBRD } \\
\text { reform indices on } \\
\text { banking and non- } \\
\text { banking financial } \\
\text { sector, see Annex } \\
1 \text { for details }\end{array}$ & $\begin{array}{l}\text { Average of EBRD } \\
\text { reform indices on } \\
\text { infrastructure } \\
\text { (telecom, rail, road, } \\
\text { water, power), see } \\
\text { Annex } 1 \text { for } \\
\text { details }\end{array}$ & $\begin{array}{l}\text { Average of EBRD } \\
\text { reform indices on } \\
\text { privatisation and } \\
\text { liberalisation, see } \\
\text { Annex } 1 \text { for } \\
\text { details }\end{array}$ & $\begin{array}{l}\text { Average of Invclim } \\
\text { and Infrastructure, } \\
\text { see Annex } 1 \\
\text { for details }\end{array}$ \\
\hline Source & WIIW* & $\begin{array}{l}\text { EBRD Transition } \\
\text { Report }\end{array}$ & $\begin{array}{l}\text { EBRD Transition } \\
\text { Report }\end{array}$ & $\begin{array}{l}\text { EBRD Transition } \\
\text { Report }\end{array}$ & $\begin{array}{l}\text { EBRD Transition } \\
\text { Report }\end{array}$ \\
\hline $\begin{array}{l}\text { Sample } \\
\text { countries }\end{array}$ & $\begin{array}{l}\text { Albania } \\
\text { Armenia } \\
\text { Azerbaijan } \\
\text { Belarus } \\
\text { Bulgaria }\end{array}$ & $\begin{array}{l}\text { Croatia } \\
\text { Czech Republic } \\
\text { Estonia } \\
\text { Georgia } \\
\text { Hungary }\end{array}$ & $\begin{array}{l}\text { Kazakhstan } \\
\text { Kyrgyz Republic } \\
\text { Latvia } \\
\text { Lithuania } \\
\text { Macedonia }\end{array}$ & $\begin{array}{l}\text { Moldova } \\
\text { Poland } \\
\text { Romania } \\
\text { Russia } \\
\text { Slovak Republic }\end{array}$ & $\begin{array}{l}\text { Slovenia } \\
\text { Tajikistan } \\
\text { Ukraine } \\
\text { Uzbekistan }\end{array}$ \\
\hline
\end{tabular}

Annex Table 3: Descriptive statistics of panel dataset

\begin{tabular}{llllll}
\hline Variable & Obs & Mean & Std. Dev. & Min & Max \\
\hline growth & 349 & 0.1 & 9.4 & -44.7 & 16.2 \\
investment/GDP & 358 & 21.2 & 7.2 & 0.9 & 56.5 \\
?investment/GDP & 334 & -0.3 & 5.3 & -47.2 & 21.8 \\
inflation & 351 & 240.4 & 996.9 & -8.6 & 15606.5 \\
crisis & 360 & 0.1 & 0.3 & 0.0 & 1.0 \\
FDI/GDP & 203 & 15.6 & 14.2 & 0.0 & 71.7 \\
Finance & 360 & 2.0 & 0.8 & 1.0 & 3.8 \\
Infrastructure & 360 & 1.8 & 0.8 & 1.0 & 3.7 \\
Service & 360 & 1.9 & 0.7 & 1.0 & 3.8 \\
Invclim & 360 & 2.7 & 0.9 & 1.0 & 3.9 \\
\hline
\end{tabular}

Note: For definition of variables see Annex Table 2.

Annex Table 4: Pair-wise correlation coefficients of variables used in panel analysis

\begin{tabular}{|c|c|c|c|c|c|c|c|c|c|c|c|}
\hline Variable & No. & 1 & 2 & 3 & 4 & 5 & 6 & 7 & 8 & 9 & 10 \\
\hline growth & 1 & 1 & & & & & & & & & \\
\hline investment/GDP & 2 & 0.10 & 1 & & & & & & & & \\
\hline ?investment/GDP & 3 & 0.30 & 0.35 & 1 & & & & & & & \\
\hline inflation & 4 & -0.30 & -0.13 & -0.05 & 1 & & & & & & \\
\hline crisis & 5 & -0.42 & -0.03 & -0.17 & 0.20 & 1 & & & & & \\
\hline FDI/GDP & 6 & 0.35 & 0.31 & -0.01 & -0.24 & -0.12 & 1 & & & & \\
\hline Finance & 7 & 0.51 & 0.16 & 0.17 & -0.27 & -0.32 & 0.72 & 1 & & & \\
\hline Infrastructure & 8 & 0.48 & 0.14 & 0.15 & -0.23 & -0.26 & 0.78 & 0.88 & 1 & & \\
\hline Service & 9 & 0.59 & 0.03 & 0.23 & -0.28 & -0.31 & 0.68 & 0.89 & 0.82 & 1 & \\
\hline Invclim & 10 & 0.51 & 0.16 & 0.16 & -0.26 & -0.30 & 0.78 & 0.97 & 0.97 & 0.88 & 1 \\
\hline
\end{tabular}

